\title{
Impact of preharvest foliar spray Chitosan, Nano-Chitosan, and Calcium Chloride Treatments on some fruit chemical Characteristics of 'Barhi' Date palm Fruits During Cold Storage
}

\author{
El-Masry, A.M., El-Badawy, H.E and El-Gioushy, S.F.* \\ Horticulture Department, Faculty of Agriculture, Benha University, Egypt \\ *Corresponding author: Email: Sherif.elgioushy@fagr.bu.edu.eg, gioushy_ah@yahoo.com
}

\begin{abstract}
"Barhi" fruits obtained from, 11 years old date palm plants are grown on a private farm (Pico) at MasrAlexandria desert road, Egypt. Date palm fruits were harvested at the Khalal stage when fruits attained full color (bright yellow) in mid-September during the 2019 and 2020 experimental seasons (one month before treatments). Fruits were delivered to a packing house on the same farm. Fruits that showed no symptoms of mechanical damage or degradation were chosen and standardized to ensure uniform size, color, and form, before being randomly assigned to one of ten groups. The goal of this study was to see how chitosan, Nano-Chitosan, and calcium chloride, used individually as safe pre-harvest treatments with different concentrations, affected some physicochemical aspects of "Barhi" date palm fruits to retain quality during cold storage and lengthen post-harvest life. Anyhow, the used pre-harvest treatments were: Control (Water only), Chitosan 1, 2 and 3 $\mathrm{g} / \mathrm{L}, \mathrm{CaCl}_{2}$ 1, 2 and 3g/L, Nano-Chitosan 1, 2 and $3 \mathrm{~cm}^{3} / \mathrm{L}$. all the treatments were added sprinkles every two weeks (two times pre-harvest) during the period from 15 August to 15 September (harvest time). Taking into consideration that sprays treatments were applied covering the whole bunch, whereas 2 liters was found to be sufficient in this concern. All treatments were very effective for improving fruit quality in terms of increasing (total soluble solids \%, total sugars, total acidity \%, TSS/acid ratio, and total soluble tannins) as compared with the control treatment. The best results concerning fruit quality and storability of Barhi date palms were obtained with the treatments Nano-Chitosan $3 \mathrm{~cm}^{3} / \mathrm{L}$. or $\mathrm{CaCl}_{2} 3 \mathrm{~g} / \mathrm{L}$.
\end{abstract}

Keywords: Barhi date palm - Chitosan- $\mathrm{CaCl}_{2}$ - Nano-Chitosan - Cold storage and Quality.

\section{Introduction}

Date palm (Phoenix dactyllifera L.) is a monoctyledonous and dioecious species belonging to Arecaceae (Palmaceae) family. It is one of the oldest fruit trees in the world. It is known as the "Tree of life" because of its resilience, low water requirements, long-term productivity, and multipurpose qualities.

The Berhi variety is one among the most popular palm date cultivars in the Mediterranean region and is commonly harvested and consumed fresh at the khalal stage, but they tend to mature quickly and enter the rutab stage under normal storage conditions (Ismail et al., 2006)

However, the economic value of the "Barhi" date decreases sharply when it ripens as surplus production has to be sold at lower prices. Thus, it is important to slow down ripening and extend the market in fruits of the "Barhi " date. The major goal of post-harvest technology and preharvest, which seeks to use safe and effective methods to maintain quality handling and transport of date fruits for local market and export. Modern technology which involves methods like the application of edible coatings, cold storage, etc. is taking advantage of the synergistic effect of different treatments to enhance the post-harvest life of climacteric fruits.

Date palm fruit post-harvest losses are a severe problem in Egypt, owing to rapid deterioration during handling, shipping, and storage. Barhi dates palm fruits, at the khalal stage are often preferred and considered a premium product because they are physiologically mature, hard, crisp, bright yellow in color and have the highest moisture (Ismail et al., 2006). This indicates the positive effect of safe postharvest coating treatments with chitosan, calcium chloride, each alone and combination of them and cold storage in retarding the fruit ripening process, maintaining quality attributes and could extend cold storage period of "Barhi" date palm by maintaining on changes of Physico-chemical characteristics.

Edible coatings with semipermeable film can prolong post-harvest fruit life by reducing moisture, respiration, gas exchange and oxidative reaction rates (Petriccione et al., 2015).

Chitosan (poly-B - (1-4) N-acetyl-d-glucose amine), is a natural antimicrobial compound. It can be obtained from crustacean shells (crabs, shrimp and crayfishes) either by chemical or microbiological processes (Devlieghere et al., 2004). Chitosan is widely used as edible coating material (Jiang et al., 2014). Using chitosan in various fruit crops is quite beneficial in previous experiments. Zhang et al. (2011) found that chitosan maintained post-harvest quality and beneficially influenced firmness, total soluble solids content, titratable acidity, ascorbic acid content and water content of citrus fruit after 56 days of storage at $15^{\circ} \mathrm{C}$. In a study on raspberries fruits, it was found that chitosan retains the key quality, reduces ethylene production and respiration 
rate, reduced weight loss, maintains fruit quality extends the cold storage period, and reduces decay (Velickova et al., 2013). Also, Shiri et al. (2013) found that coating table grapes with 0.5 percent or $1 \%$ chitosan and storing them at $0{ }^{\circ} \mathrm{C}$ for 60 days resulted in decreased weight loss, deterioration, and higher levels of titratable acidity. El-Wahab et al. (2014) found that $1 \%$ chitosan $+4 \%$ calcium chloride decreased weight loss and delayed the changes in firmness, titratable acidity, total soluble solids, vitamin C, anthocyanin content and respiration rate of Crimson seedless grape during storage periods compared with control. In addition, (Kamal et al., 2014) discovered that Zaghloul date palms treated chitosan $1 \%$ as post-harvest treatments gave the lowest significant weight loss $\%$ and the highest flesh firmness during cold storage at the end of 90 days. In fruits and vegetables, post-harvest treatment with $\mathrm{CaCl} 2$ delayed ripening and reduced degradation (El-Gamal et al., 2007), and lowered the rate of senescence and fruit ripening of pear under cold storage (Mahajan and Dhatt, 2004).

To postpone fruit maturity, many methods have been used, including low-temperature storage (AlEid et al., 2012 \& Kamal et al., 2014). Cold storage, is taking advantage of the synergistic effect to enhance the post-harvest life of climacteric fruits. Higazy et al. (2002) found that storing Zaghloul fruits at $0{ }^{\circ} \mathrm{C}$ reduced weight loss and prolonged storage life.

The goal of this study was to see how chitosan, Nano-Chitosan, and calcium chloride, used individually as safe pre-harvest treatments, affected some physicochemical aspects of "Barhi" date palm fruits to retain quality during storage and lengthen post-harvest life.

\section{Materials and Methods}

\section{Fruit material:-}

"Barhi" fruits obtained from, 11 years old palms grown on a private farm (Pico) at Masr-Alexandria desert road, Egypt. Date Palm fruits were (one month after treatments) harvested at Khalal stage when fruits when attained full color (bright yellow) according to (Iqbal $\boldsymbol{e t}$ al., 2004) in mid-September during 2019 and 2020 experimental seasons. The fruit was delivered to a packing house on the same farm. Fruits that showed no symptoms of mechanical damage or degradation were chosen and standardized to ensure uniform size, color, and form, before being randomly assigned to one of ten groups.

\section{Preparation of coating solutions:-}

\section{a. Preparation of chitosan:-}

High purity, low-molecular-weight chitosan powder food grade was used to preparation of solution; 10, 20 and $30 \mathrm{~g}$ of chitosan was added to $100 \mathrm{ml}$ of acetic acid solution (1\% v/v) and gently mixed at $40{ }^{\circ} \mathrm{C}$ on a magnetic stirrer. Subsequently, $0.75 \mathrm{ml} / \mathrm{g}$ of glycerol was added as the plasticizer and $0.2 \%$ of Tween 80 was added as the emulsifier. The $\mathrm{pH}$ was then adjusted to $5.7-6$ by adding 1 $\mathrm{mol} / \mathrm{L} \mathrm{NaOH}$, and then the solution was steered at $30^{\circ} \mathrm{C}$ for $30 \mathrm{~min}$. The prepared solution was then filtrated through Whatman filter papers and autoclaved for $15 \mathrm{~min}$ at $121{ }^{\circ} \mathrm{C}$ (Ojagh et al., 2010).

\section{b. Calcium chloride:-}

$1,2,3 \mathrm{~g}(\mathrm{w} / \mathrm{v})$ solution was prepared by dissolving 1,2 and $3 \mathrm{~g} / 100$ of $\mathrm{CaCl}_{2}$ in $1000 \mathrm{~mL}$ of distilled water. The solution was agitated constantly using a magnetic stirrer for 30 minutes and $0.2 \mathrm{~mL}$ of Tween 20 was added to the solution to improve wettability.

\section{Preparation of Chitosan Nano-particles:}

Chitosan Nanoparticles were prepared according to the ion tropic gelatin procedure developed by (Calvo et al., 1998) and modified by (Domaratzki $\boldsymbol{e t}$ al 2008). The accurate weight of chitosan (1mg/ml) was dissolved in $0.175 \%$ acetic acid (v/v). Sodium tripolyphosphate (TPP) was dissolved in deionized water at the concentration of $2 \mathrm{mg} / \mathrm{ml}$. Both the chitosan and TPP solutions were dissolved under constant magnetic stirring at room temperature for 30 minutes at $900 \mathrm{rpm}$. Once both solutions were individually mixed they were passed through a syringe filter. A $0.45 \mu \mathrm{m}$ syringe filter was used for chitosan and a $0.22 \mu \mathrm{m}$ filter was used for TPP. The TPP was added to chitosan to form nanoparticles. A chitosan to TPP ratio of 5:1 was chosen based on the work of Zhang et al (2004) and confirmed by Domaratzki et al. (2008). Chitosan -TPP nanoparticles spontaneously formed by the TPP initiated ionic gelatin mechanism upon the addition of aqueous TPP solutions to the chitosan solutions (at chitosan to TPP volume ratio $5: 1$ ). This was done under mild constant magnetic stirring at room temperature for 1 minute at $100 \mathrm{rpm}$. Then it was centrifuged (Beckman Coulter Ultracentrifuge. California. the USA) for 30 minutes at $52000 \mathrm{xg}$ to isolated the nanoparticles.

The formation of chitosan nanoparticles could be controlled simply by varying the key processing conditions of chitosan concentration, TPP concentration, and solution PH. Within the tested range of conditions, an increase in particle size showed a simple linear relationship to increasing TPP concentration. Solution $\mathrm{pH}$ and chitosan concentration also had a profound influence on the stability of the nanoparticle system (Tang-Qian $\boldsymbol{e t}$ al., 2007a).

They used ten pre-harvest treatments were:

* Taking into consideration that, the following spray was two times before harvest intervals 15 days.

1. Control (Water only).

2. Foliar spray with Chitosan at $1 \mathrm{~g} / \mathrm{L}$.

3. Foliar spray with Chitosan at $2 \mathrm{~g} / \mathrm{L}$.

4. Foliar spray with Chitosan at $3 \mathrm{~g} / \mathrm{L}$.

5. Foliar spray with $\mathrm{CaCl}_{2}$ at $1 \mathrm{~g} / \mathrm{L}$.

6. Foliar spray with $\mathrm{CaCl}_{2}$ at $2 \mathrm{~g} / \mathrm{L}$. 
7. Foliar spray with $\mathrm{CaCl}_{2}$ at $3 \mathrm{~g} / \mathrm{L}$.

8. Foliar spray with Nano-Chitosan at $1 \mathrm{Cm}^{3}$.

9. Foliar spray with Nano-Chitosan at $2 \mathrm{Cm}^{3}$.

10. Foliar spray with Nano-Chitosan at $3 \mathrm{Cm}^{3}$.

The treated and non-treated fruits were divided into different lots and transferred to the post-harvest laboratory after harvest directly.

\section{Storage fruits:}

Fruits from each treatment were packed in performing carton boxes $(30 * 40 * 20 \mathrm{~cm})$ and store at cold temperature $0^{\circ} \mathrm{C}$ with $90-95 \% \mathrm{RH}$ for each treatment, the first box to determine decay $\%$ and the second box to determine weight loss and third box to determine fruit quality, each box contained $(2 \mathrm{~kg}$ of fruits/ replicate) was replicated three times, and the experiment was repeated twice (2015 and 2016 seasons). During the storage period, all the physical characteristics (weight loss, firmness and color) and chemical characteristics (total phenol, total sugars, total Tannins and enzyme activity) will be determined in fruits sample every 15 days at different sampling times (i.e. At harvest, 15, 30, 45, 60, 75 and 90) days.

\section{Chemical properties:}

4.1. Total soluble solids percentage (T.S.S. \%) of the pulp was estimated by abbey digital refractometer, according to the Association of Official Analytical Chemists (A.O.A.C.) (1995).

4.2. TSS/acid ratio: TSS/acid ratio was estimated by dividing the total soluble solids percentage over the total acidity percentage.

4.3. Total sugars percentage: Soluble sugars were colorimetrically adjusted in the dried fruit pulp extracted with water according to the modification done by Smith et al., (1956). Soluble sugars were calculated as the percentage of glucose in fruit dry pulp.

4.4. Reducing and non-reducing sugars: The percentages of total, reducing and non-reducing sugars were determined according to Lane and Eynon (1965) volumetric method outlined in the Association of Official Analytical Chemists (A.O.A.C.) (1995). Non-reducing sugars percentage was determined by calculating the differences between total sugars and reducing sugars.

4.5. Total fruit tannins (\%): Total tannins concentration of date fruit peel was determined using the method described by Resenabatt and Pelluso (1941). Tannins concentration was determined from the standard curve of tannic acid. The tannins acid concentration was expressed as a percentage.

\section{5- Statistical analysis:}

All results of physicochemical parameters were performed in triplicate using a completely randomized factorial design. Data were analyzed with the Analysis of variance (ANOVA) procedure of the MSTAT-C program. When significant differences were detected, treatment means were compared by LSD range test at the 5\% level of probability in the two investigated seasons (Snedecor and Cochran, 1980).

\section{Results and Discussions}

\section{Chemical characteristics}

a. Total soluble solids (T.S.S.)

Data showed the effect of pre-harvest treatments on TSS percentage of "Barhi date palm fruits during cold storage at $0^{\circ} \mathrm{C}$ and $90-95 \% \mathrm{RH}$ for 70 days are presented in Table (1). TSS increased with extending of the storage period reaching the maximum values at a storage period of (70 days) for Barhi date palm cultivar. Generally, it could be mentioned that all safe post-harvest treatments caused significantly lower TSS values than the untreated fruits during the two seasons of the study compared with control. At the end of the storage period, it appeared that the highest percentage of T.S.S. was obtained in control fruits (35.74 \& 35.78\%). Meanwhile, the lowest means values were obtained from Chitosan Nanomaterial at $\left(3 \mathrm{Cm}^{3}\right)$ recorded $(33.31 \& 33.91 \%)$; followed by Chitosan Nanomaterial at $\left(2 \mathrm{Cm}^{3}\right)$ recorded $(33.40 \& 33.92 \%)$ followed by Chitosan Nanomaterial $1 \mathrm{Cm}^{3}$ recorded $(33.57 \& 34.08 \%)$ and then $\mathrm{CaCl}_{2} 3 \mathrm{~g} / \mathrm{L}$. (33.68 \& 34.02) and $\mathrm{CaCl}_{2} 2 \mathrm{~g} / \mathrm{L}$ recorded (33.86 \& 34.09); followed by $\mathrm{CaCl}_{2} 1 \mathrm{~g} / \mathrm{L}$ treatment recorded $(33.86 \& 34.13 \%)$ and then Chitosan $(3 \mathrm{~g} / \mathrm{L}) ;(2 \mathrm{~g} / \mathrm{L})$ and $(1 \mathrm{~g} / \mathrm{L})$ recorded $(33.95$ $\& 34.30 \%)$; (33.99 \& $34.36 \%)$ and $(34.21 \& 34.48$ $\%)$ respectively in descending order gave the lowest values of T.S.S during 2019 and 2020 seasons respectively compared with the untreated fruits (34.61 \& 35.22\%).

Evaluating the interaction effect between storage periods and safe post-harvest treatments, data showed that the interactions of 90 days cold storage period, registered the highest values of fruit total soluble solids percentage, are in untreated fruits (control) in both seasons. All post-harvest coating treatments showed the lowest increase in TSS. The loss of a substantial portion of water enhances the concentration of soluble solids. This issue makes the fruit much sweeter (Mortazavi et al., 2010).

The lower TSS is due to the slower change from carbohydrates to sugars (Rohani et al., 1997).

TSS showed an increasing trend during fruit development at cold storage. High TSS values represent the high percentage of sugars; fruit sweetening in the final stages of development is seen in most fruits and can be attributed to the hydrolytic conversion of insoluble carbohydrates into soluble sugars (Saleem et al., 2005). But in the case of date fruit, the loss of a substantial portion of water 
enhances the concentration of soluble solids. This issue affects both the taste and the texture of date fruit and makes the fruit much sweeter (Mortazavi et al., 2010)

Similar results in mango fruit coated with chitosan had less soluble solids than fruits untreated. Also, in papaya, chitosan provided an effective control in delayed changes in soluble solids concentration during 5 weeks of storage (Ali et al., 2011). A similar effect was observed for that chitosan decreases the respiration rates, delays ripening (Du and Iwahroi, 1997) and slow rise in TSS (Zhang et al. 2011). Meanwhile, The effect of calcium in reducing the TSS content of fruits, reducing the rate of senescence and fruit ripening (Mahajan and Dhatt, 2004). Chitosan coating combined with calcium slowed the ripening of papaya as shown by their retention delay insoluble solid increase.

\section{b. T.S.S/acidity ratio.}

Data concerning the effect of pre-harvest foliar spray treatments on T.S.S/acidity ratio of "Barhi date palm during storage at $0^{\circ} \mathrm{C}$ and $90-95 \%$ R.H. for 70 days are presented in Table (2). The TSS/acid ratio increased with extending the storage periods reaching the maximum values at storage periods of (70 days) for the Barhi cultivar. Overall, it could be mentioned that all safe post-harvest treatments caused significantly lower TSS/acidity ratio values than the initial periods (untreated fruits) during the two seasons of study. At the end of the storage period, it appeared that the highest percentage of T.S.S./acidity ratio was obtained in control fruits (208.4 \& 289.5). While, the lowest means values were obtained from Chitosan Nanomaterial $\left(3 \mathrm{~cm}^{3}\right)$ recorded (114.7 \& 124.3); followed by $\mathrm{CaCl}_{2} 3 \mathrm{~g} / \mathrm{L}$. recorded (118.0 and 127.2) followed by Chitosan Nanomaterial $\left(2 \mathrm{~cm}^{3}\right)(118.2 \& 129.4)$ and $\mathrm{CaCl}_{2}$ 2g/L. (120.6 \& 133.1); $\mathrm{CaCl}_{2} 2 \mathrm{~g} / \mathrm{L}$ and Chitosan Nanomaterial $1 \mathrm{~cm}^{3}$ recorded $(122.2 \& 135.1)$ then and Chitosan Nanomaterial $1 \mathrm{~cm}^{3}$ and $\mathrm{CaCl}_{2} 1 \mathrm{~g} / \mathrm{L}$ recorded (124.7 \& 137.9); followed by Chitosan (3 g/L) (125.3 \& 141.7); Chitosan (2g/L) (128.6 \& 146.5) and Chitosan (1 g/L) (136.7 \& 159.5$)$; respectively in descending order gave the lowest values of T.S.S/acidity during both seasons, respectively.

\section{c. Total sugars:}

Data mentioned that the effect of different preharvest treatments on total soluble sugars content of stored "Barhi " date palm fruits is presented in Table (3).

It is obvious that total soluble sugars increased gradually and significantly with extending of storage period as previously detected by Davarynejad $\boldsymbol{e t}$ al ., (2013).

While, the control treatment resulted in higher and faster increase in total soluble sugars during cold storage than that occurred in fruits treated with postharvest treatments at the two seasons of this study. In this respect; chitosan Nanomaterial $3 \mathrm{~cm}^{3}$ (31.22 \& $31.52 \%)$ followed by chitosan Nanomaterial $2 \mathrm{~cm}^{3}$ (31.26 \& $31.26 \%$ ) followed by $\mathrm{CaCl}_{2} 3 \mathrm{~g} / \mathrm{L}$ and $2 \mathrm{~g} / \mathrm{L}$ (31.27 and $31.76 \%$ ) and then $\mathrm{CaCl}_{2} 2 \mathrm{~g} / \mathrm{L}$ and chitosan Nanomaterial $1 \mathrm{~cm}^{3}$ treatments $(31.32 \& 31.78 \%)$ and then chitosan Nanomaterial $1 \mathrm{~cm}^{3}$ and $\mathrm{CaCl} 23 \mathrm{~g} / \mathrm{L}$ (31.33 \& $31.81 \%$ ) followed by $\mathrm{CaCl} 21 \mathrm{~g} / \mathrm{L}$ recorded (31.40 \& $31.85 \%)$; Chitosan alone at $3 \mathrm{~g} / \mathrm{L} ; 2 \mathrm{~g} / \mathrm{L}$ and 1 $\mathrm{g} / \mathrm{L}(31.40 \& 31.90 \%) ;(31.48 \& 31.96 \%)$ and (31.54 $\&$ 32.05) treatments in descending order gave the lowest values of total sugars as compared with the control treatment which recorded the highest values of total sugars (32.21 \& $32.53 \%)$ for both investigate seasons.

Furthermore, the effect of interaction effect revealed that at the end of the storage period (70 days), fruits treated with the pre-harvest treatments initial periods showed the lowest values of total sugars compared with untreated fruits in the first and second seasons.

It could be said that increasing total soluble sugars may be due to increasing hydrolysis of starch and polysaccharides to soluble sugars during cold storage.

All pre-harvest treatments decline increases in total soluble sugars, whereas, the control gave the highest content of total sugars in both seasons. This may be because the high respiration of control fruit converts stored sugars or starch into energy and advances ripening.

The increase in sugars content of fruits could be due to the ripening process that led to the transformation of some carbohydrates components as starch to sugars by the enzymatic activities (Karemera1 and Habimana, 2014).

The higher total sugar content as "Barhi " date palm fruits passed from the Khalal to Rutab (full ripen fruits or softening) stage (El-Rayes, 2009).

Fruit sweetening in the final stages of development is seen in most fruits and can be attributed to the hydrolytic conversion of insoluble carbohydrate polymers into low-density soluble sugars (Saleem et al., 2005).

\section{d. Reducing sugars:}

Data in Table (4) refer to the reducing sugars content was significantly increased with prolonging cold storage periods. The control treatments showed the highest values of reducing sugars content. Chitosan Nanomaterial $3 \mathrm{~cm}^{3}$ recorded $(28.2 \& 29.47)$ followed by Chitosan Nanomaterial $3 \mathrm{~cm}^{3}$ and $\mathrm{CaCl} 21 \mathrm{~g} / \mathrm{L}$ recorded (28.28 \& 29.52) followed by $\mathrm{CaCl} 23 \mathrm{~g} / \mathrm{L}$ and Chitosan Nanomaterial $2 \mathrm{~cm}^{3}$ recorded (28.33 \& 29.53) and then Chitosan Nanomaterial $1 \mathrm{~cm}^{3}$ and $\mathrm{CaCl} 23 \mathrm{~g} / \mathrm{L}$ recorded (28.34 \& 29.54) and then $\mathrm{CaCl} 22 \mathrm{~g} / \mathrm{L}(28.34$ $\&$ 29.58) and followed by $\mathrm{CaCl} 21 \mathrm{~g} / \mathrm{L}$ and Chitosan Nanomaterial $1 \mathrm{~cm}^{3}$ (28.45 \& 29.60) and then Chitosan $3 \mathrm{~g} / \mathrm{L}$ (28.49 \& 29.86); Chitosan $2 \mathrm{~g} / \mathrm{L}$ (28.64 \& 29.86) and Chitosan $1 \mathrm{~g} / \mathrm{L}(28.64 \& 29.90)$ treatments in descending order gave the lowest values of reducing sugars as compared with the control treatment which 
recorded the highest values of reducing sugars $(29.18 \&$ $30.18 \%$ ) for 2019 and 2020 seasons, respectively.

Data showed that interaction of the treatments and cold storage period recorded the highest values percentage of reducing sugars are in the control treatment (untreated fruits) in both seasons. All postharvest safe treatments showed the lowest increase in reducing sugars.

The higher reducing sugar in "Barhi" date palm fruits during pass fruit from Khalal stage to rutab stage (EL-Rayes, 2009).

\section{e. Non reducing g sugars:}

As shown in Tables (5), it is clear that the average non-reducing sugars values decreased as the storage period increased reaching its lowest values of non-reducing sugars at the end of the storage period 70 days in all pre-harvest treatments. The highest significant mean values of "Barhi" date palm nonreducing sugars obtained from untreated (control) gave (3.28 \& 2.35) followed by Chitosan $1 \mathrm{~g} / \mathrm{L}$ and $\mathrm{CaCl} 23 \mathrm{~g} / \mathrm{L}$ recorded (3.22 \& 2.28) followed by Chitosan Nanomaterial $3 \mathrm{Cm}^{3} \&$ and $\mathrm{CaCl} 21 \mathrm{~g} / \mathrm{L}$ gave (3.02 \& 2.23) and then Chitosan Nanomaterial $2 \mathrm{Cm}^{3}$ and $\mathrm{CaCl} 2$ 2g/L recorded (2.99 \& 2.19) followed by Chitosan Nanomaterial $1 \mathrm{Cm}^{3}$ (2.97 \& 2.18) followed by $\mathrm{CaCl} 21 \mathrm{~g} / \mathrm{L} \&$ Chitosan $1 \mathrm{~g} / \mathrm{L}$ (2.95 \& 2.16), $\mathrm{CaCl} 23 \mathrm{~g} / \mathrm{L} \&$ Chitosan $2 \mathrm{~g} / \mathrm{L}$ or $3 \mathrm{~g} / \mathrm{L}$ (2.93 \& 2.10) and finally Chitosan $2 \mathrm{~g} / \mathrm{L}$ or $3 \mathrm{~g} / \mathrm{L} \&$ Chitosan Nanomaterial $3 \mathrm{Cm}^{3}$ gave $(2.90 ; 2.91 \&$ 2.05) respectively in both seasons. In addition, control (water only) combination with the end of storage period reflected the highest non-reducing sugars for "Barhi" date palm fruits; meanwhile, untreated fruits gave the highest non-reducing sugars in this respect concerning the effect of the interaction during the different periods of storage in 2019 and 2020 seasons of study.

Chitosan alone pre-harvest treatment significantly inhibited the softening of "Barhi" date palm fruits resulting from the degradation of the middle lamella of the cell wall of cortical parenchyma cells (Perkins-Veazie, 1995). Calcium is a major component of the total; reducing and non-reusing parameters and has a role in strengthening cell wall and membrane structure and it plays a significant role in retarding of these parameters (Oms-Oliu $\boldsymbol{e t}$ al., 2010).

\section{Total tannins:}

The effects of the pre-harvest treatments on "Barhi" date palm total tannins content were found to be statistically significant Table (6). At the end of the 70 days storage period, the total tannins content of fruits was decreased during both seasons of study, respectively.

While, decline was much higher in control; all postharvest coating treatments inhibited the decline of total tannins specially (Chitosan Nanomaterial $3 \mathrm{~cm}^{3} ; \mathrm{CaCl}_{2} 3 \mathrm{~g} / \mathrm{L}$.; Chitosan Nanomaterial $2 \mathrm{~cm}^{3} \& \mathrm{CaCl}_{2} 3 \mathrm{~g} / \mathrm{L}$.) and
(Chitosan Nanomaterial $3 \mathrm{~cm}^{3} ; \mathrm{CaCl}_{2} 3 \mathrm{~g} / \mathrm{L}$.) gave the highest statistically values $(0.225 ; 0.220 ; 0.219$ \& $0.214)$ and $(0.208 \& 0.205)$ in total tannins in the 2019 and 2020 seasons, respectively. Interaction data show significant differences between various treatments and storage periods, the highest total tannins content was obtained from "Barhi" date palm fruits coated with chitosan Nanomaterial $3 \mathrm{~cm}^{3}$ and $\mathrm{CaCl} 23 \mathrm{~g} / \mathrm{L}$ treatments compared to control fruits recorded the highest decline of means total tannins ( $0.131 \& 0.119)$.

Minimum decrease of total tannins during storage showed from different post-harvest edible coatings of "Barhi" date palm fruits especially with chitosan only.

This could be due to postharvest treatments slowed tannin degradation by reducing the respiration rate and created a modified atmosphere inside the fruit that affect its metabolism (Guilbert et al., 1996) as extend the khalal stage and delayed the entrance in rutab stage so, helped to delay ripening and preserved quality of "Barhi" date palm fruits.

Al-Redhaiman (2004) reported that total tannins content decreased as "Barhi" dates matured from the khalal stage (Bisr or full mature stage of development) to the ripe stage (rutab). Tannin compounds are present as a layer below the skin of the date and consist mainly of polyphenols and flavones, which are broken down during maturation and converted to insoluble compounds that have no astringency (Tafti \& Fooladi, 2005). In this study, soluble tannins concentrations in fruits by safe postharvest treatment application might be due to their influence in the delayed fruit ripening process.

The present results supported by evidence that Chitosan alone or combined with calcium chloride coated grape (El-Wahab et al., 2014), Aloe vera coated sweet cherry and Papaya (Martinez- Romero et al., 2006; Marpudi et al., 2011) and Propolis extract coated sweet cherries (Candir et al., 2009) as helped to delay ripening, preserve fruit quality and prolong the shelf life. 
Table 1. The effect of preharvest Chitosan, Nano-Chitosan and calcium chloride foliar spray treatments on total soluble solids (TSS) (\%) of Barhi date fruits under cold storage during 2019/2020 experimental seasons.

\begin{tabular}{|c|c|c|c|c|c|c|c|c|c|}
\hline \multirow[b]{2}{*}{ Treatments } & \multicolumn{8}{|c|}{ Storage periods } & \multirow[b]{2}{*}{ Mean } \\
\hline & 0.0 days & 10 days & 20 days & 30 days & 40 days & 50 days & 60 days & 70 days & \\
\hline & \multicolumn{9}{|c|}{ First season; 2019} \\
\hline Control (Water only). & 32.51 & 33.12 & 33.56 & 34.16 & 35.02 & 35.43 & 36.19 & 37.26 & $34.61 \mathrm{~A}$ \\
\hline Chitosan $1 \mathrm{~g} / \mathrm{L}$. & 2.51 & 32.61 & 33.19 & 34.01 & 34.55 & 35.00 & 35.68 & 36.11 & $4.21 \mathrm{~B}$ \\
\hline Chitosan $2 \mathrm{~g} / \mathrm{L}$. & 32.51 & 32.63 & 32.95 & 33.59 & 34.19 & 34.77 & 35.34 & 35.97 & $33.99 \mathrm{C}$ \\
\hline Chitosan $3 \mathrm{~g} / \mathrm{L}$. & 32.51 & 32.71 & 32.85 & 33.58 & 34.13 & 34.75 & 35.20 & 35.90 & $33.95 \mathrm{C}$ \\
\hline $\mathrm{CaCl}_{2} 1 \mathrm{~g} / \mathrm{L}$ & 32.51 & 32.56 & 32.96 & 33.56 & 34.03 & 34.59 & 35.09 & 35.57 & $33.86 \mathrm{D}$ \\
\hline $\mathrm{CaCl}_{2} 2 \mathrm{~g} / \mathrm{L}$ & 32.51 & 32.54 & 32.96 & 33.56 & 34.06 & 34.68 & 35.06 & 35.52 & $33.86 \mathrm{D}$ \\
\hline $\mathrm{g} / \mathrm{L}$ & 2.51 & 32.54 & 32.75 & 33.14 & 33.90 & 34.31 & 34.88 & 35.39 & $33.68 \mathrm{E}$ \\
\hline Chitosan Nanomaterial $1 \mathrm{Cm}^{3}$. & 32.51 & 32.58 & 32.87 & 33.05 & 33.33 & 33.90 & 34.46 & 35.82 & $33.57 \mathrm{~F}$ \\
\hline in Nanom & 32.51 & 32.53 & 32.85 & 32.99 & 33.24 & 33.66 & 34.38 & 35.02 & $33.40 \mathrm{G}$ \\
\hline Chitosan Nanomaterial $3 \mathrm{Cm}^{3}$. & 32.51 & 32.53 & 32.75 & 32.91 & 33.22 & 33.59 & 34.12 & 34.81 & $33.31 \mathrm{H}$ \\
\hline Mean & $32.51 \mathrm{H}$ & $32.64 \mathrm{G}$ & $32.97 \mathrm{~F}$ & $33.46 \mathrm{E}$ & 33.97D & $34.47 \mathrm{C}$ & $35.04 \mathrm{~B}$ & $35.74 \mathrm{~A}$ & \\
\hline \multirow[t]{2}{*}{ L.S.D at $5 \%$ for: } & Treatme & nts $(\mathrm{A})=$ & $=0.0476$ & Storage $\mathrm{p}$ & eriods $(\mathrm{B})$ & $=0.0426$ & $\mathrm{Ax}$ & $\mathrm{B}=0.1$ & 346 \\
\hline & \multicolumn{9}{|c|}{ Second season; 2020} \\
\hline Con & & 64 & 34.48 & 34.79 & 35.71 & 36.12 & 36.87 & 37.11 & $22 \mathrm{~A}$ \\
\hline Chitosan $1 \mathrm{~g} / \mathrm{L}$. & $33 .($ & 33.22 & 33.73 & & 34.70 & & & & \\
\hline Chitosan $2 \mathrm{~g} / \mathrm{L}$. & 33.03 & 33.19 & 33.42 & 33.96 & 34.63 & 35.01 & 35.52 & 36.10 & $34.36 \mathrm{C}$ \\
\hline Chitosan $3 \mathrm{~g} / \mathrm{L}$. & 33.03 & 33.28 & 33.38 & & 34.52 & 34.91 & 35.41 & 35.95 & 34.30D \\
\hline $\mathrm{g} / \mathrm{L}$ & 33.03 & 33.11 & 33.44 & 33.87 & 34.26 & 34.68 & 34.99 & 35.65 & $34.13 \mathrm{E}$ \\
\hline $\mathrm{g} / \mathrm{L}$ & 33.03 & 33.08 & 33.50 & 33.85 & 34.21 & 34.57 & 34.96 & 35.55 & 34.09EF \\
\hline $\mathrm{CaCl}_{2} 3 \mathrm{~g} / \mathrm{L}$ & 33.03 & 33.07 & 33.37 & 33.82 & 34.13 & 34.49 & 34.91 & 35.36 & $34.02 \mathrm{G}$ \\
\hline Chitosan Nanomaterial $1 \mathrm{Cm}^{3}$. & 33.03 & 33.10 & 33.32 & 33.92 & 34.21 & 34.61 & 34.99 & 35.47 & $34.08 \mathrm{FG}$ \\
\hline san Nanom & 33.03 & 33.07 & 33.21 & 33.34 & 34.11 & 34.46 & 34.83 & 35.30 & $33.92 \mathrm{H}$ \\
\hline Chitosan Nanomaterial $3 \mathrm{Cm}^{3}$. & 33.03 & 33.07 & 33.18 & 33.61 & 34.02 & 34.41 & 34.80 & 35.19 & $33.91 \mathrm{H}$ \\
\hline & $33.03 \mathrm{H}$ & $33.18 \mathrm{G}$ & $33.50 \mathrm{~F}$ & $33.93 \mathrm{E}$ & $34.45 \mathrm{D}$ & $34.84 \mathrm{C}$ & $35.30 \mathrm{~B}$ & $35.78 \mathrm{~A}$ & \\
\hline L.S.D at $5 \%$ for: & Treatme & nts $(\mathrm{A})=$ & $=0.0509$ & Storage $\mathrm{p}$ & eriods $(\mathrm{B})$ & $=0.0455$ & & $\mathrm{x} \mathrm{B}=0.1$ & 439 \\
\hline
\end{tabular}

Table 2. The effect of preharvest Chitosan, Nano-Chitosan and calcium chloride foliar spray treatments on TSS/acidity ratio (\%) of Barhi date fruits under cold storage during 2019/2020 experimental seasons.

\begin{tabular}{|c|c|c|c|c|c|c|c|c|c|}
\hline \multirow[b]{2}{*}{ Treatments } & \multicolumn{8}{|c|}{ Storage periods } & \multirow[b]{2}{*}{ Mean } \\
\hline & 0.0 days & 10 days & 20 days & 30 days & 40 days & 50 days & 60 days & 70 days & \\
\hline & \multicolumn{9}{|c|}{ First season; 2019} \\
\hline Control (Water only). & & & & & & 241.0 & 309.3 & & \\
\hline Chitosan $1 \mathrm{~g} / \mathrm{L}$. & & & & 130.8 & 142.2 & 150.2 & 167.5 & 187.1 & \\
\hline Chitosan $2 \mathrm{~g} / \mathrm{L}$. & 98.5 & 102.9 & 108.7 & 121.3 & 131.5 & 143.1 & 151.7 & 171.3 & $128.6 \mathrm{C}$ \\
\hline Chitosan $3 \mathrm{~g} / \mathrm{L}$. & .5 & 103.2 & 107.0 & 118.7 & 129.8 & 135.2 & 146.7 & 163.2 & $3 \mathrm{D}$ \\
\hline $\mathrm{CaCl}_{2} 1 \mathrm{~g} / \mathrm{L}$ & .5 & 104.0 & 105.3 & 116.9 & 122.9 & 131.5 & 142.1 & 6.7 & $2 \mathrm{E}$ \\
\hline $\mathrm{CaCl}_{2} 2 \mathrm{~g} / \mathrm{L}$ & 98.5 & 105.0 & 105.3 & 114.5 & 123.0 & 129.9 & 136.4 & 152.4 & $120.6 \mathrm{E}$ \\
\hline $\mathrm{CaCl}_{2} 3 \mathrm{~g} / \mathrm{L}$ & .5 & 101.7 & 103.3 & 0.5 & 118.1 & 127.1 & 135.7 & 9.3 & $118.0 \mathrm{~F}$ \\
\hline Chitosan Nanomaterial $1 \mathrm{Cm}^{3}$. & 98.5 & 104.1 & 109.6 & 115.2 & 128.2 & 131.9 & 145.4 & 165.1 & $124.7 \mathrm{D}$ \\
\hline Chitosan Nanomate & 98.5 & 102.6 & 107.0 & 111.1 & 117.5 & 124.7 & 133.8 & 150.3 & \\
\hline Chitosan Nanomaterial $3 \mathrm{Cm}^{3}$. & 98.5 & 100.7 & 103.3 & 109.7 & 113.4 & 121.3 & 127.8 & 143.3 & $114.7 \mathrm{G}$ \\
\hline Mean & $98.5 \mathrm{H}$ & $104.0 \mathrm{G}$ & $108.6 \mathrm{~F}$ & $122.6 \mathrm{E}$ & $132.2 \mathrm{D}$ & $143.6 \mathrm{C}$ & $159.6 \mathrm{~B}$ & $183.9 \mathrm{~A}$ & \\
\hline \multirow[t]{2}{*}{ L.S.D at $5 \%$ for: } & \multicolumn{3}{|c|}{ Treatments $(\mathrm{A})=1.798$} & \multicolumn{3}{|c|}{ Storage periods $(\mathrm{B})=1.608$} & \multicolumn{3}{|c|}{$\mathrm{A} \times \mathrm{B}=5.085$} \\
\hline & \multicolumn{9}{|c|}{ Second season; 2020} \\
\hline Control (Water only). & 106.5 & 121.4 & 145.5 & 180.3 & 227.5 & 319.6 & 423.8 & 9.6 & $289.5 \mathrm{~A}$ \\
\hline san $1 \mathrm{~g} / \mathrm{L}$ & 106.5 & 114.6 & 128.3 & 144.5 & 159.9 & 178.3 & 213.8 & 230.0 & $.5 \mathrm{~B}$ \\
\hline Chitosan $2 \mathrm{~g} / \mathrm{L}$. & 106.5 & 109.5 & 118.1 & 127.2 & 148.6 & 169.1 & 184.0 & 208.7 & $146.5 \mathrm{C}$ \\
\hline Chitosan $3 \mathrm{~g} / \mathrm{L}$. & 106.5 & 108.4 & 116.3 & 127.0 & 142.1 & 163.9 & 177.1 & 192.2 & $141.7 \mathrm{D}$ \\
\hline $\mathrm{CaCl}_{2} 1 \mathrm{~g} / \mathrm{L}$ & 106.5 & 107.9 & 114.1 & 124.1 & 141.0 & 155.5 & 169.0 & 184.7 & $137.9 \mathrm{E}$ \\
\hline $\mathrm{CaCl}_{2} 2 \mathrm{~g} / \mathrm{L}$ & 106.5 & 107.8 & 114.3 & 120.9 & 135.2 & 148.4 & 156.8 & 175.1 & $133.1 \mathrm{G}$ \\
\hline $\mathrm{CaCl}_{2} 3 \mathrm{~g} / \mathrm{L}$ & 106.5 & 107.7 & 112.4 & 117.8 & 126.4 & 131.1 & 149.8 & 166.0 & $127.2 \mathrm{I}$ \\
\hline Chitosan Nanomaterial $1 \mathrm{Cm}^{3}$. & 106.5 & 110.3 & 113.7 & 124.2 & 130.1 & 140.1 & 159.0 & 197.1 & $135.1 \mathrm{~F}$ \\
\hline
\end{tabular}




\begin{tabular}{cccccccccc}
\hline Chitosan Nanomaterial $2 \mathrm{Cm}^{3}$. & 106.5 & 107.7 & 111.8 & 116.2 & 126.3 & 134.1 & 153.4 & 179.2 & $129.4 \mathrm{H}$ \\
Chitosan Nanomaterial $3 \mathrm{Cm}^{3}$. & 106.5 & 107.7 & 109.5 & 114.7 & 120.2 & 128.9 & 145.0 & 162.2 & $124.3 \mathrm{~J}$ \\
Mean & $106.5 \mathrm{H}$ & $110.3 \mathrm{G}$ & $118.4 \mathrm{~F}$ & $129.7 \mathrm{E}$ & $145.7 \mathrm{D}$ & $166.9 \mathrm{C}$ & $193.2 \mathrm{~B}$ & $248.5 \mathrm{~A}$ \\
L.S.D at 5 \% for: & \multicolumn{7}{c}{ Treatments (A) $=1.852$} & Storage periods $(\mathrm{B})=1.656$ & A x B $=5.237$ \\
\hline
\end{tabular}

Table 3. The effect of preharvest Chitosan, Nano-Chitosan and calcium chloride foliar spray treatments on total sugars (\%) of Barhi date fruits under cold storage during 2019/2020 experimental seasons.

\begin{tabular}{|c|c|c|c|c|c|c|c|c|c|}
\hline \multirow[b]{2}{*}{ Treatments } & \multicolumn{8}{|c|}{ Storage periods } & \multirow[b]{2}{*}{ Mean } \\
\hline & \multicolumn{8}{|c|}{ First season; 2019} & \\
\hline Control (Water ol & & & & 31.33 & 32.17 & 33.15 & 34.10 & 34.79 & $32.21 \mathrm{~A}$ \\
\hline Chitosan $1 \mathrm{~g} / \mathrm{L}$. & 30.51 & 30.56 & 30.76 & & 31.32 & 32.14 & 32.72 & 33.25 & \\
\hline Chitosan $2 \mathrm{~g} / \mathrm{L}$. & & & & & & & & 33.20 & \\
\hline Chitosan $3 \mathrm{~g} / \mathrm{L}$. & 30. & 30. & 30 . & & & 31.77 & 32.53 & 33.09 & 31.40DE \\
\hline $\mathrm{CaCl}_{2} 1 \mathrm{~g} / \mathrm{L}$ & & & & & & & & 33.05 & ODE \\
\hline $\mathrm{CaCl}_{2} 2 \mathrm{~g} / \mathrm{L}$ & & 30 & 30 & & & 31.63 & 32.23 & 32.97 & $2 \mathrm{~F}$ \\
\hline $\mathrm{CaCl}_{2} 3 \mathrm{~g} / \mathrm{L}$ & & 30. & 30. & & & 31.42 & 32.19 & 32.92 & $7 \mathrm{G}$ \\
\hline Chitosan Nanomaterial $1 \mathrm{Cm}^{3}$. & 30. & 30. & 30. & & & 31.62 & 32.32 & 32.92 & $3 \mathrm{EF}$ \\
\hline Chitosan Nanoma & & 30. & 30. & & & 31.43 & 32.26 & 32.91 & $5 \mathrm{GH}$ \\
\hline Chitosan Nanomat & & 30 . & & & & & 32.19 & 32.82 & $31.22 \mathrm{H}$ \\
\hline Mean & $30.51 \mathrm{G}$ & $30.57 \mathrm{G}$ & $30.70 \mathrm{~F}$ & $30.94 \mathrm{E}$ & $31.23 \mathrm{D}$ & $31.82 \mathrm{C}$ & $32.56 \mathrm{~B}$ & 33.19A & \\
\hline \multirow[t]{2}{*}{ L.S.D at $5 \%$ for: } & \multicolumn{3}{|c|}{ Treatments $(\mathrm{A})=0.0441$} & \multicolumn{3}{|c|}{ Storage periods $(\mathrm{B})=0.0394$} & \multicolumn{3}{|c|}{$\mathrm{A} \times \mathrm{B}=0.1246$} \\
\hline & \multicolumn{9}{|c|}{ Second season; 2020} \\
\hline Control (Wate & & & & 31.97 & & 33.03 & & 34.60 & \\
\hline Chitosan $1 \mathrm{~g} / \mathrm{L}$. & & 31.09 & 31.27 & & & 32. & & 33.71 & \\
\hline Chitosan $2 \mathrm{~g} / \mathrm{L}$. & & 31.07 & 31.21 & & & 32 & & 33.63 & \\
\hline Chitosan $3 \mathrm{~g} / \mathrm{L}$. & & 31.04 & 31.18 & & & 32.31 & 33.03 & 33.54 & $90 \mathrm{D}$ \\
\hline $\mathrm{CaCl}_{2} 1 \mathrm{~g} / \mathrm{L}$ & & 31.02 & 31.21 & & & 32.21 & 32.99 & 33.42 & $85 \mathrm{E}$ \\
\hline $\mathrm{CaCl}_{2} 2 \mathrm{~g} / \mathrm{L}$ & & & & & & & & 33.23 & \\
\hline $\mathrm{CaCl}_{2} 3 \mathrm{~g} / \mathrm{L}$ & & 31.01 & 31.10 & 31.30 & 31.91 & 32.19 & 32.73 & 33.33 & $31.81 \mathrm{EF}$ \\
\hline Chitosan Nanomaterial $1 \mathrm{Cm}^{3}$. & & 31.03 & 31.11 & 31.31 & & 32.21 & 32.82 & 33.29 & $31.78 \mathrm{FG}$ \\
\hline Chitosan Nanom & 30.95 & & & & & 32.04 & 32.75 & 33.23 & $31.72 \mathrm{H}$ \\
\hline Chitosan Nanomaterial $3 \mathrm{Cm}^{3}$. & 30.95 & 30.99 & 30.06 & 31.19 & 31.41 & 31.96 & 32.51 & 33.05 & $31.52 \mathrm{I}$ \\
\hline & $30.95 \mathrm{G}$ & $31.06 \mathrm{~F}$ & $31.10 \mathrm{~F}$ & $31.42 \mathrm{E}$ & $31.78 \mathrm{D}$ & $32.31 \mathrm{C}$ & $32.98 \mathrm{~B}$ & $33.50 \mathrm{~A}$ & \\
\hline L.S.D at $5 \%$ for: & Treatme & ents $(A)=$ & $=0.0402$ & Storage $\mathrm{pe}$ & eriods (B) & $=0.0360$ & & $\mathrm{x} \mathrm{B}=0.1$ & 1137 \\
\hline
\end{tabular}


Table 4. The effect of preharvest Chitosan, Nano-Chitosan and calcium chloride foliar spray treatments on reducing-sugars (\%) of Barhi date fruits under cold storage during 2019/2020 experimental seasons.

\begin{tabular}{|c|c|c|c|c|c|c|c|c|c|}
\hline \multirow[b]{2}{*}{ Treatments } & \multicolumn{8}{|c|}{ Storage periods } & \multirow[b]{2}{*}{ Mean } \\
\hline & 0.0 days & 10 days & 20 days & 30 days & 40 days & 50 days & 60 days & 70 days & \\
\hline & \multicolumn{9}{|c|}{ First season; 2019} \\
\hline Control (Water only). & 27.30 & 27.93 & 28.33 & 28.78 & 29.23 & 30.00 & 30.66 & 31.19 & $29.18 \mathrm{~A}$ \\
\hline Chitosan $1 \mathrm{~g} / \mathrm{L}$. & 27.30 & 27.81 & 28.00 & 28.21 & 28.52 & 29.11 & 29.52 & 30.66 & 28.64B \\
\hline Chitosan $2 \mathrm{~g} / \mathrm{L}$. & 27.30 & 28.14 & 27.97 & 28.16 & 28.48 & 29.03 & 29.50 & 30.00 & 28.57B \\
\hline Chitosan $3 \mathrm{~g} / \mathrm{L}$. & 27.30 & 27.73 & 27.96 & 28.15 & 28.46 & 28.93 & 29.42 & 29.98 & $28.49 \mathrm{C}$ \\
\hline $\mathrm{CaCl}_{2} 1 \mathrm{~g} / \mathrm{L}$ & 27.30 & 27.68 & 27.91 & 28.15 & 28.43 & 28.90 & 29.35 & 29.84 & $28.45 \mathrm{D}$ \\
\hline $\mathrm{CaCl}_{2} 2 \mathrm{~g} / \mathrm{L}$. & 27.30 & 27.63 & 27.76 & 27.92 & 28.33 & 28.71 & 29.26 & 29.79 & $28.34 \mathrm{E}$ \\
\hline $\mathrm{CaCl}_{2} 3 \mathrm{~g} / \mathrm{L}$ & 27.30 & 27.61 & 27.72 & 27.89 & 28.29 & 28.78 & 29.31 & 29.77 & $28.33 \mathrm{E}$ \\
\hline Chitosan Nanomaterial $1 \mathrm{Cm}^{3}$. & 27.30 & 27.67 & 27.79 & 27.92 & 28.37 & 28.74 & 29.21 & 29.72 & $28.34 \mathrm{E}$ \\
\hline Chitosan Nanomaterial $2 \mathrm{Cm}^{3}$. & 27.30 & 27.63 & 27.76 & 27.89 & 28.29 & 28.63 & 29.13 & 29.57 & $28.28 \mathrm{~F}$ \\
\hline Chitosan Nanomaterial $3 \mathrm{Cm}^{3}$. & 27.30 & 27.60 & 27.71 & 27.83 & 28.21 & 28.51 & 29.01 & 29.43 & $28.20 \mathrm{G}$ \\
\hline Mean & $27.30 \mathrm{H}$ & $27.74 \mathrm{G}$ & $27.89 \mathrm{~F}$ & $28.09 \mathrm{E}$ & $28.46 \mathrm{D}$ & $28.93 \mathrm{C}$ & \multicolumn{3}{|c|}{$29.44 \mathrm{~B} 30.00 \mathrm{~A}$} \\
\hline L.S.D at $5 \%$ for: & \multicolumn{6}{|c|}{$\begin{array}{r}\text { Treatments }(A)=0.0360 \begin{array}{l}\text { Storage periods }(B)=0.0322 \\
\text { Second season; } 2020\end{array}\end{array}$} & \multicolumn{3}{|c|}{$\mathrm{A} \times \mathrm{B}=0.1017$} \\
\hline Control (Water only). & 28.15 & 28.95 & 29.37 & 29.81 & 30.26 & 31.03 & 31.71 & 32.17 & $30.18 \mathrm{~A}$ \\
\hline Chitosan $1 \mathrm{~g} / \mathrm{L}$ & 28.15 & 28.80 & 29.21 & 29.70 & 30.00 & 30.68 & 31.10 & 31.52 & $29.90 \mathrm{~B}$ \\
\hline Chitosan $2 \mathrm{~g} / \mathrm{L}$. & 28.15 & 28.76 & 29.18 & 29.67 & 29.97 & 30.62 & 31.05 & 31.44 & $29.86 \mathrm{C}$ \\
\hline Chitosan $3 \mathrm{~g} / \mathrm{L}$. & 28.15 & 28.73 & 29.15 & 29.62 & 29.88 & 30.51 & 31.02 & 31.37 & $29.80 \mathrm{D}$ \\
\hline $\mathrm{CaCl}_{2} 1 \mathrm{~g} / \mathrm{L}$ & 28.15 & 28.71 & 29.00 & 29.35 & 29.70 & 30.27 & 30.88 & 30.11 & $29.52 \mathrm{E}$ \\
\hline $\mathrm{CaCl}_{2} 2 \mathrm{~g} / \mathrm{L}$. & 28.15 & 28.64 & 28.92 & 29.23 & 29.66 & 30.24 & 30.71 & 31.05 & $29.58 \mathrm{~F}$ \\
\hline $\mathrm{CaCl}_{2} 3 \mathrm{~g} / \mathrm{L}$ & 28.15 & 28.63 & 28.85 & 29.19 & 29.58 & 30.21 & 30.67 & 31.02 & $29.54 G$ \\
\hline Chitosan Nanomaterial $1 \mathrm{Cm}^{3}$. & 28.15 & 28.67 & 29.01 & 29.31 & 29.64 & 30.26 & 30.71 & 31.07 & $29.60 \mathrm{~F}$ \\
\hline Chitosan Nanomaterial $2 \mathrm{Cm}^{3}$. & 28.15 & 28.63 & 28.87 & 29.19 & 29.57 & 30.22 & 30.63 & 30.97 & $29.53 \mathrm{G}$ \\
\hline Chitosan Nanomaterial $3 \mathrm{Cm}^{3}$. & 28.15 & 28.61 & 28.81 & 29.15 & 29.40 & 30.19 & 30.54 & 30.91 & $29.47 \mathrm{H}$ \\
\hline Mean & $28.15 \mathrm{H}$ & $28.71 \mathrm{G}$ & $29.04 \mathrm{~F}$ & $29.42 \mathrm{E}$ & 29.77D & $30.42 \mathrm{E}$ & $30.90 \mathrm{~B}$ & $31.26 \mathrm{~A}$ & \\
\hline L.S.D at $5 \%$ for: & Treatme & $\operatorname{nts}(A)=$ & $=0.0312$ & Storage $\mathrm{pe}$ & eriods (B & $=0.0279$ & & $\mathrm{~B}=0.0$ & 881 \\
\hline
\end{tabular}

Table (5): The effect of preharvest Chitosan, Nano-Chitosan and calcium chloride foliar spray treatments on Non-reducing-sugars (\%) of Barhi date fruits under cold storage during 2019/2020 experimental seasons.

\begin{tabular}{|c|c|c|c|c|c|c|c|c|c|}
\hline \multirow[b]{2}{*}{ Treatments } & \multicolumn{8}{|c|}{ Storage periods } & \multirow[b]{2}{*}{ Mean } \\
\hline & 0.0 days & 10 days & 20 days & 30 days & 40 days & 50 days & 60 days & 70 days & \\
\hline & \multicolumn{9}{|c|}{ First season; 2019} \\
\hline Control (Water only). & 3.21 & 3.79 & 3.59 & 2.55 & 2.94 & 3.15 & 3.43 & 3.60 & $3.28 \mathrm{~A}$ \\
\hline Chitosan $1 \mathrm{~g} / \mathrm{L}$. & 3.21 & 3.80 & 3.76 & 2.81 & 2.80 & 3.03 & 3.19 & 3.19 & $3.22 \mathrm{~B}$ \\
\hline Chitosan $2 \mathrm{~g} / \mathrm{L}$. & 3.21 & 2.45 & 2.75 & 2.84 & 2.77 & 2.90 & 3.08 & 3.20 & $2.90 \mathrm{E}$ \\
\hline Chitosan $3 \mathrm{~g} / \mathrm{L}$. & 3.21 & 2.83 & 2.74 & 2.76 & 2.69 & 2.85 & 3.11 & 3.12 & $2.91 \mathrm{E}$ \\
\hline $\mathrm{CaCl}_{2} 1 \mathrm{~g} / \mathrm{L}$ & 3.21 & 2.90 & 2.78 & 2.75 & 2.74 & 2.84 & 3.17 & 3.22 & $2.95 \mathrm{DE}$ \\
\hline $\mathrm{CaCl}_{2} 2 \mathrm{~g} / \mathrm{L}$ & 3.21 & 2.92 & 2.93 & 2.98 & 2.78 & 2.92 & 2.97 & 3.18 & $2.99 \mathrm{CD}$ \\
\hline $\mathrm{CaCl}_{2} 3 \mathrm{~g} / \mathrm{L}$ & 3.21 & 2.94 & 2.93 & 2.97 & 2.75 & 2.64 & 2.88 & 3.15 & $2.93 \mathrm{DE}$ \\
\hline Chitosan Nanomaterial $1 \mathrm{Cm}^{3}$. & 3.21 & 2.90 & 2.86 & 2.92 & 2.71 & 2.88 & 3.11 & 3.20 & $2.97 \mathrm{CD}$ \\
\hline Chitosan Nanomaterial $2 \mathrm{Cm}^{3}$. & 3.21 & 2.90 & 2.86 & 2.91 & 2.73 & 2.80 & 3.13 & 3.34 & $2.99 \mathrm{CD}$ \\
\hline Chitosan Nanomaterial $3 \mathrm{Cm}^{3}$. & 3.21 & 2.94 & 2.90 & 2.97 & 2.72 & 2.84 & 3.18 & 3.40 & $3.02 \mathrm{C}$ \\
\hline Mean & $3.21 \mathrm{~A}$ & 3.04B & $3.01 \mathrm{C}$ & $2.85 \mathrm{E}$ & $2.76 \mathrm{~F}$ & $2.89 \mathrm{D}$ & $3.13 \mathrm{AB}$ & $3.26 \mathrm{~A}$ & \\
\hline L.S.D at $5 \%$ for: & \multicolumn{3}{|c|}{ Treatments $(A)=0.022$} & \multicolumn{3}{|c|}{$\begin{array}{c}\text { Storage periods }(B)=0.0197 \\
\text { Second season; } 2020\end{array}$} & \multicolumn{3}{|c|}{$\mathrm{A} \times \mathrm{B}=0.0623$} \\
\hline Control (Water only). & 2.80 & 2.42 & 2.29 & 2.16 & 2.50 & 2.00 & 2.22 & 2.43 & $2.35 \mathrm{~A}$ \\
\hline Chitosan $1 \mathrm{~g} / \mathrm{L}$ & 2.80 & 2.29 & 2.06 & 1.90 & 2.01 & 1.99 & 2.04 & 2.20 & $2.16 \mathrm{E}$ \\
\hline Chitosan $2 \mathrm{~g} / \mathrm{L}$. & 2.80 & 2.31 & 2.03 & 1.87 & 1.87 & 1.75 & 2.00 & 2.19 & $2.10 \mathrm{~F}$ \\
\hline Chitosan $3 \mathrm{~g} / \mathrm{L}$. & 2.80 & 2.31 & 2.03 & 1.79 & 1.85 & 1.79 & 2.02 & 2.17 & $2.10 \mathrm{~F}$ \\
\hline $\mathrm{CaCl}_{2} 1 \mathrm{~g} / \mathrm{L}$ & 2.80 & 2.32 & 2.21 & 2.21 & 1.92 & 1.94 & 2.11 & 2.31 & $2.23 \mathrm{C}$ \\
\hline $\mathrm{CaCl}_{2} 2 \mathrm{~g} / \mathrm{L}$ & 2.80 & 2.37 & 2.20 & 2.09 & 1.85 & 1.86 & 2.16 & 2.18 & $2.19 \mathrm{CD}$ \\
\hline $\mathrm{CaCl}_{2} 3 \mathrm{~g} / \mathrm{L}$ & 2.80 & 2.38 & 2.25 & 2.11 & 2.33 & 1.98 & 2.06 & 2.31 & $2.28 \mathrm{~B}$ \\
\hline Chitosan Nanomaterial $1 \mathrm{Cm}^{3}$. & 2.80 & 2.36 & 2.10 & 2.00 & 1.86 & 1.95 & 2.11 & 2.22 & $2.18 \mathrm{DE}$ \\
\hline Chitosan Nanomaterial $2 \mathrm{Cm}^{3}$. & 2.80 & 2.37 & 2.20 & 2.02 & 1.90 & 1.82 & 2.11 & 2.26 & $2.19 \mathrm{CD}$ \\
\hline Chitosan Nanomaterial $3 \mathrm{Cm}^{3}$. & 2.80 & 2.39 & 1.26 & 2.04 & 2.01 & 1.77 & 1.97 & 2.14 & $2.05 \mathrm{G}$ \\
\hline
\end{tabular}




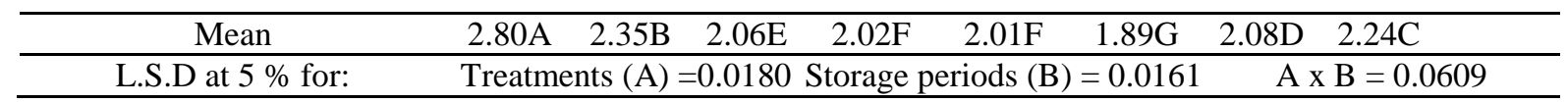

Table 6. The effect of preharvest Chitosan, Nano-Chitosan and calcium chloride foliar spray treatments on total tannins (\%) of Barhi date fruits under cold storage during 2019/2020 experimental seasons.

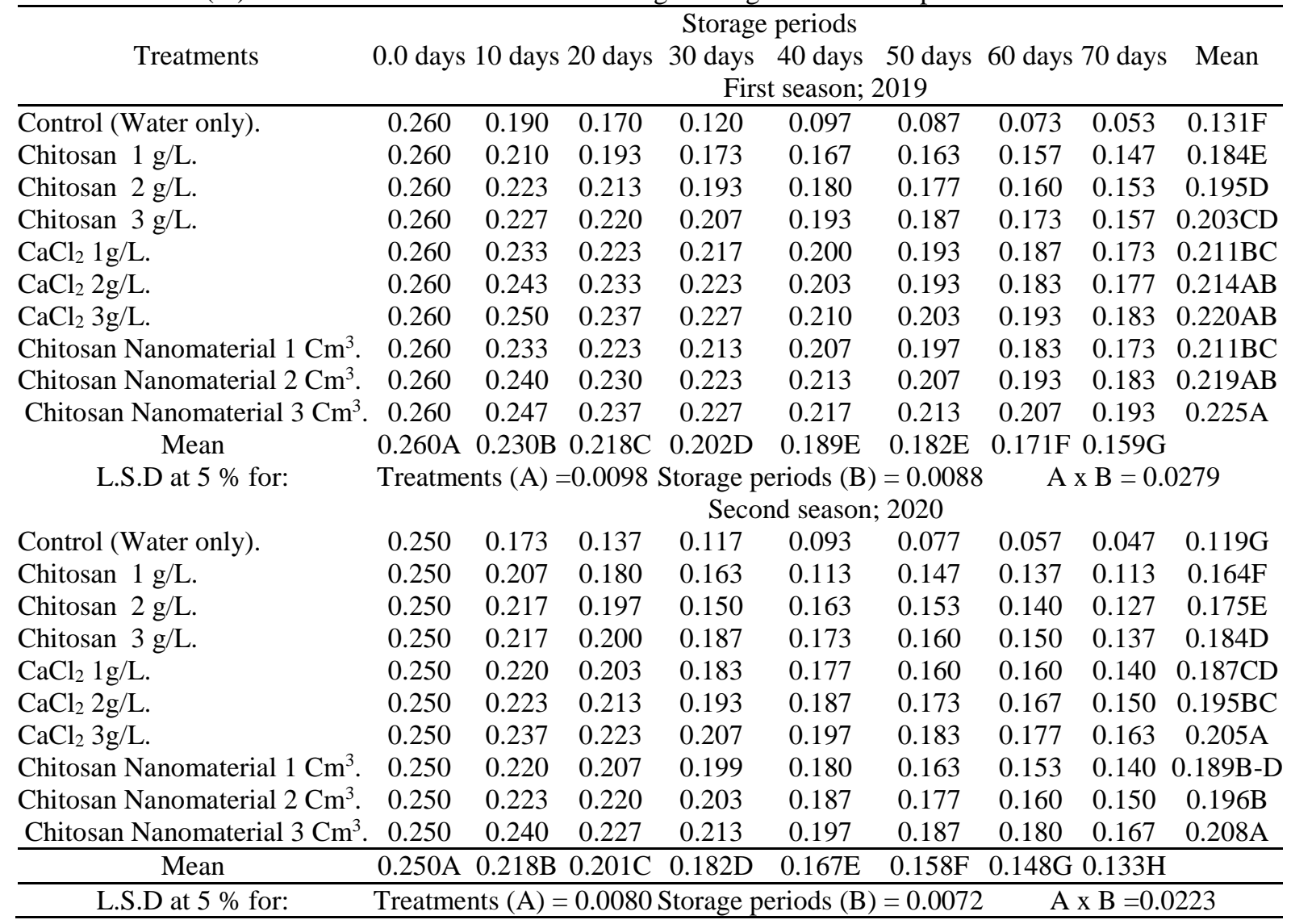

\section{References}

Abd El-Kader Boufersaoui (2016). The date in all its forms $2^{\text {nd }}$ International Conference for date palm (ICDP 2016) in Qassim, Kingdom of Saudi Arabia, from 10-12 October.

Al-Eid, S.M., Barber, A.B., Rettke, M., Leo, A., Alsenaien, W.A. and Sailam, A.A. (2012). Utilisation of modified atmosphere packaging to extend the shelf life of khalas fresh dates. International Journal of Food Science and Technology, 74, 1518-1525.

Ali, A., Muhammad, M.T.M., Sijam, K., Siddiqui, Y., (2011). Effect of chitosan coatings on the physicochemical characteristics of Eksotika II papaya (Carica papayaL.) fruit during cold storage. Food Chem. 124, 620-626.

Al-Redhaiman, K.N. (2004). Modified atmosphere improves storage ability, controls decay and maintains quality and antioxidant contents of brahi date fruits. Food Agriculture and Environment. 2, $25-32$.

A.O.A.C. (1995). Association of Official Analytical Chemists. Official Methods of Analysis, $15^{\text {th }}$ ed. Washington, D.C., USA.

Baliga, M.S., B.R.V. Baliga, S.M. Kandathil, H.P. Bhat and P.K. Vayalil (2011). A Review of the
Chemistry and Pharmacology of the Date Fruits (Phoenix dactylifera L.). Food Res. Int. 44:18121822.

Calvo, P. C. , J. L Remuñán-López, J.L. Vila-Jato and M. J.Alonso (1998). Novel hydrophilic chitosan-polyethylene oxide nanoparticles as protein carriers. Journal of Applied Polymer science. 12(2).pp125-132.

Chao, C.T., and Krueger, R.R. (2007). The date palm (Phoenix dactylifera L.): overview of biology, uses, and cultivation. HortScience, 42(5), 1077-1082.

Davarynejad, G., M. Zarei, E. Ardakani, M. E. Nasrabadi (2013). Influence of Putrescine Application on Storability, Post-harvest Quality and Antioxidant Activity of Two Iranian Apricot (Prunus armeniaca L.) Cultivars, Notulae Scientia Biologicae, 5(2):212-219.

Devlieghere, F., Vermeulen, A. and Debevere, J. (2004). Chitosan: antimicrobial activity, interactions with food components and applicability as a coating on fruit and vegetables. Food Microbiol., 21: 703-714.

Domaratzki, R.E. and A.Ghanem (2008). Encapsulation and release of cladribine from 
chitosan nanoparticles. J. Appl. Polym. Sci. 128, pp2173-2179.

Du, J., Gemma, H. and Iwahori, S. (1997). Effects of chitosan coating on the storage of peach, Japanese pear and kiwifruit. J. Jpn. Hort. Sci. 66, 15-22.

Dubois, M.K., A. Gilles, J.K. Hamilton, P.A. Reders, and F. Smith, (1956). Colorimetric method for determination of sugars and related substances. Analytical Chemistry, 28(3): 350356.

El-Gamal, Nadia, G.; Abd El-Kareem, F. Fotouh, Y.O. and El-Mougy-Nehal, S. (2007). Induction of systemic resistance in potato plants against late and early blight diseases using chemical inducers under greenhouse and field conditions. Research Conditions. Res. J. of Agr. And Biol. Sci, 3 (2): 73-81

El-Rayes, D.A. (2009) Effect of Carbon DioxideEnriched Atmosphere during Cold Storage on Limiting Antioxidant Losses and Maintaining Quality of 'Barhy' Date Fruits. JKAU: Met., Env. \& Arid Land Agric. Sci., 20(1): 3-22.

El-Wahab, W.A., Elwahab, S.M. and Kamel, O.T. (2014). Using Safe Alternatives for Controlling Post-harvest Decay, Maintaining Quality of Crimson Seedless.World Applied Sciences Journal 31 (7): 1345-1357.

Guilbert, S., Contard, N. and Gorris, L.G.M. (1996). Prolongation of the shelf-life of perishable food products using biodegradable films and coatings. Lebensmittel-Wissenschaft \& Technologie, 29, $10-17$.

Higazy, M.K., Fahmy, M.A., Sobeih, M.E. and ElSamad, M.A. (2002). The effect of post-harvest treatments on Zaghloul date fruits during storage. J. Agric. Sci. Mansoura Univ., 27 (12): 8221 8232.

Iqbal, M.; Ghafoor, A. and Rahman, S. (2004). Effect of pollination times on fruits characteristics and yield of date palm cv. Dhakki. Int. J. Agric. Biol.6,96-99.

Ismail, B., Haffar, I., Baalbaki, R., Mechref, Y. and Henry, J. (2006). Physico-chemical characteristics and total quality of five date varieties grown in the United Arab Emirates. Int. J. Food Sci. Technol. 41:919-926.

Jiang, T., Deng, M., James, R., Nair, L.S., Laurencin, C.T. (2014). Micro- and nanofabrication of chitosan structures for regenerative engineering. Acta Biomater. 10 (4), 1632-1645.

Kamal, H.M, El-Wahab, S.M., Farrag, A.H, and Zainhoum, A.A. (2014). Improving fruit quality and Storability of Zaghloul Date Palm Fruits By using Safe Pre and Post-harvest Substance. J. Biol. Chem. Environ. Sci. (10):2243-265.

Karemera1, N.J and U. Habimana, (2014). Effect of pre-harvest calcium chloride on post-harvest behavior of Mango fruits (Mangifera indica L.) cv. Alphonso. Universal Journal of Agricultural Research, 2(3): 119-125.

Lane, J.H. and L. Eynon (1965). Determination of reducing sugars of means of Fehlings solutions with methylene blue as indicator A.O.A.C. Washington D.C., U.S.A.

Mahajan, B. V.C and Dhatt, A.S. (2004). Studies on postharvest Calcium application on storage and quality of Asian pear during cold storage. Intl. j. Food Agri. And Environment 157-159:2.

Marpudi, S.L., Abirami, L.S.S., Pushkala, R .and Srividya, N. (2011). Enhancement of storage life and quality maintenance of papaya fruits using Aloe vera based antimicrobial coating, Indian Journal of Biotechnology 10,83-89.

Martinez-Romero, D., Alburquerque, N., Valverde, J.M., Guillen, F., Castillo, S., Valero, D., Serrano, M. (2006). Postharvest sweet cherry quality and safety maintenanceby Aloe vera treatment: a new edible coating. Postharvest Biol. Technol. 39,93-100

Miller, G.L. (1972). Use of dinitrosalicyclic acid reagent of determination of reducing sugar, Anal. Chem. 31: 426-428.

Mitra, S.K. and Baldwin, E.A. (1997). Mango. In Post-harvest Physiology and Storage of Tropical and Sub Tropical Fruits, International, New York, NY. 85-122.

Mortazavi, S.M.H., K. Arzani and M. Barzegar (2010). Analysis of Sugars and Organic Acids Contents of Date Palm (Phoenix dactylifera L.) Barhee During Fruit Development. Acta Hort. 882:793-801.

Ojagh, S. M., Rezaei, M., Razavi, S. H. and Hosseini, S. M. H. (2010). Effect of chitosan coatings enriched with cinnamon oil on the quality of refrigerated rainbow trout. Food Chemistry, 120(1), 193-198.

Oms-Oliu, G., M.A. Rojas-Grau, L.A. Gonzalez, P. Varela, R. Soliva-Fortuny, M.I.H. Hernando, I.P . Munuera, S. Fiszman and O. Martin Bllos, (2010). Recent approaches using chemical treatments to preserve quality of freshcut fruits: A review postharvest Biol. Tech., 57: 139-148.

Perkins-Veazie, P. (1995). Growth and ripening of strawberry fruit. Hortic. Rev. 17, 267-297.

Petriccione, M. M, Astrobuoni, F.P, Asquarielloetal, M.S. (2015). Effect of chitosan coating on the post-harvest quality and antioxidant enzyme system response of strawberry fruit during cold storage. Foods. (4):4: 501-523.

Resenabatt, M. and Pelluso, J.V. (1941). Determination of tannins by spectra photometer. J.

Rohani, M.Y., Zaipun, M.Z. and Norhayati, M. (1997). Effect of modified atmosphere on the storage life and quality of Eksotika papaya. J. Trop. Agric. Food Sci., 25: 103-113. 
Saleem, A.S., A.K. Baloch, M.K. Baloch, W.A. Baloch and A. Ghaffoor. (2005). Accelerated Ripening of Dhakki Dates by Artificial Means: Ripening by Acetic Acid and Sodium Chloride. J. Food Eng. 70:61-66.

Shiri, M., Bakhsh, A.D., Ghasemnezhad, M., Dadi, M., Papchatzis M.A. and Kalorizou, $\mathbf{H}$. (2013). Chitosan coating improves the shelf life and post-harvest quality of table grape (Vitis vinifera) cultivar Shahroudi. Turk. J. Agric. For., 37: 148-156.

Smith, F.; A. M. Cilles; K. J. Hamilton and A. P. Gedes (1956). Colorimetric methods for determination of sugar and related substances. Annuals chem.. 28: 350 .

Snedecor, G.W. and Cochran, W.G. (1980). Statistical Methods $6^{\text {th }}$ edition Oxford and IBH publishing Co. New Delhi, pp: 503..

Swain, T. and W.E. Hillis, (1959). The qualitative analysis of phenolic constituent J.Soc.Food.Agric., 10:63.

Tafti, A.G. and Fooladi, M.H. (2005). Changes in physical and chemical characteristic of mozafati date fruit during development. Journal of Biological Sciences. 5, 319-322.

Tang, Z.X., J.Q. Qian and L.E. Shi (2007a). Preparation of chitosan nanoparticles as carrier for immobilized enzyme. Applied Biochemistry and Biotechnology volume, 136:77-96.

Tang, Z.X., J.Q. Qian and L.E. Shi (2007b). Characterizations of immobilized neutral lipase on chitosan nano-particles. Materials Letters. 61(1): 37-40.

Velickova, E., Winkelhausen, E., Kuzmanova, S., Alves, V. D., and Moldão-Martins, M. (2013). Impact of chitosan-beeswax edible coatings on the quality of fresh strawberries (Fragaria ananassa cv Camarosa) under commercial storage conditions. LWT-Food Science and Technology, 52(2), 80-92.

Wang, J.; Wang, B.; Jiang, W. and Zhao, Y. (2007). Quality and marketing life of mango (Mangifera indica L. cv. 'Tainong') coated by using chitosan and polyphenols. Food Science and Technology International, 13(4):317-322

Zhang, H., Li, R. and Liu, W. (2011). Effect of chitin and its derivative chitosan on post-harvest decay of fruits: A Review. Int. J. Mol. Sci., 12: 917-934.

Zhang, Y.C., R. Xing and X.Y. Hu (2004). A green hydrothermal route to copper nanocrystallites. J. Crystal Growth 273: pp280284. 


\section{تأثير معاملات ما قبل الحصاد بالثيتوزان والناتو شيتوزان وكلوريد الكالسيوم على بعض الخصائص الكيمائية لثمار

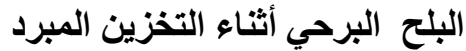

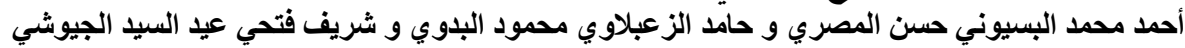

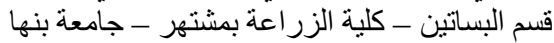

أجريت هذه الدر اسة خلال مو سمي

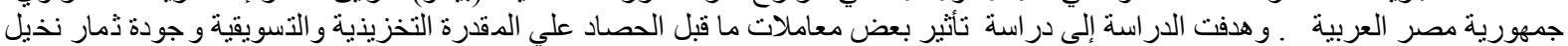
البلح البرحي.

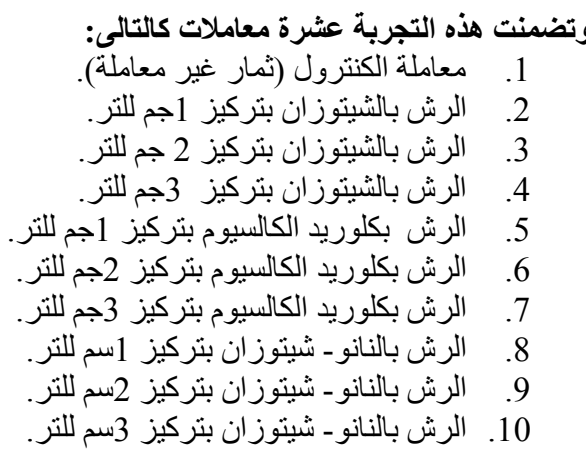

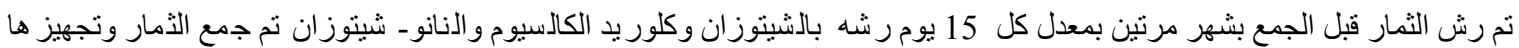

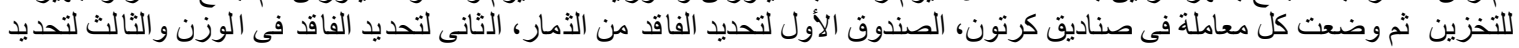

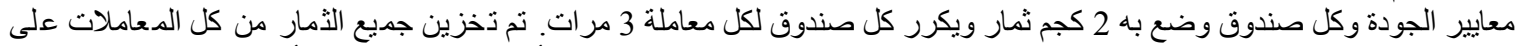

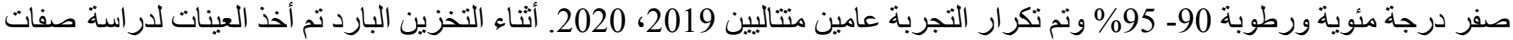

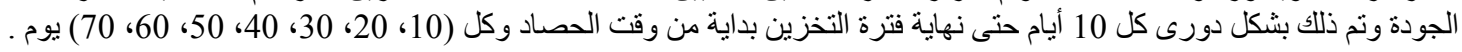

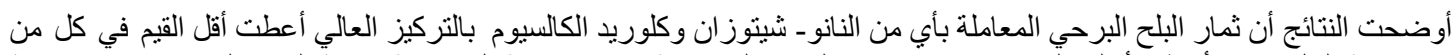

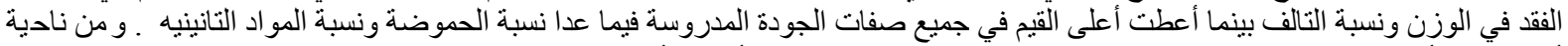

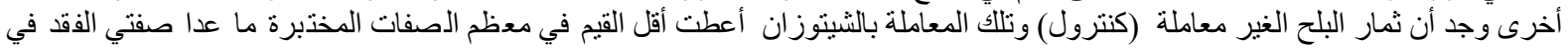

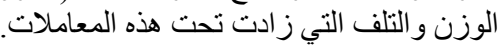
الكلمات الدالة: البلح البرحي_ الثيتوزان ـكلوريد الكالسيوم ـ نسبة التلف ـ الفقد في الوزن ــ السكريات الكلية . 